This Accepted Author Manuscript is copyrighted and published by Elsevier. It is posted here by agreement between Elsevier and University of Brasilia. Changes resulting from the publishing process - such as editing, corrections, structural formatting, and other quality control mechanisms - may not be reflected in this version of the text. The definitive version of the text was subsequently published in [Animal Reproduction Science, Volume 97, Issue 3-4, February 2007, Pages Pages 323-333, doi:10.1016/j.anireprosci.2006.02.010].You may download, copy and otherwise use the AAM for non-commercial purposes provided that your license is limited by the following restrictions:

(1) You may use this AAM for non-commercial purposes only under the terms of the CC-BY-NCND license.

(2) The integrity of the work and identification of the author, copyright owner, and publisher must be preserved in any copy.

(3) You must attribute this AAM in the following format: [agreed attribution language, including link to CC BY-NC-ND license + Digital Object Identifier link to the published journal article on Elsevier's ScienceDirect ${ }^{\circledR}$ platform].

Este Manuscrito do Autor Aceito para Publicação (AAM) é protegido por direitos autorais e publicado pela Elsevier. Ele esta disponível neste Repositório, por acordo entre a Elsevier e a Universidade de Brasília. As alterações decorrentes do processo de publicação - como a edição, correção, formatação estrutural, e outros mecanismos de controle de qualidade - não estão refletidas nesta versão do texto. A versão definitiva do texto foi posteriormente publicado em [Animal Reproduction Science, Volume 97, Número 3-4, Fevereiro 2007, Páginas Pages 323-333 doi:10.1016/j.anireprosci.2006.02.010]. Você pode baixar, copiar e utilizar de outra forma o AAM para fins não comerciais , desde que sua licença seja limitada pelas seguintes restrições: (1) Você pode usar este AAM para fins não comerciais apenas sob os termos da licença CC- BYNC-ND.

(2) A integridade do trabalho e identificação do autor, detentor dos direitos autorais e editor deve ser preservado em qualquer cópia.

(3) Tem de atribuir este AAM no seguinte formato: [acordo na linguagem atribuída, incluindo o link para CC BY-NC-ND licença Digital + DOI do artigo publicado na revista Elsevier ScienceDirect ${ }^{\circledR}$ da plataforma]. 


\title{
Ultrastructural and morphometric characterization of buffalo (Bubalus bubalis) ovarian preantral follicles
}

\author{
R.G. Mondadoria \\ M.C.A. Luque \\ R. Santin
}

S.N. Báo

\begin{abstract}
The main objective of the present study was to characterize buffalo preantral ovarian follicles. Parts of ovarian cortex, collected from postpubertal buffalo females that were having estrous cycles at regular intervals, were selected under stereomicroscopy and processed for optic and transmission electron microscopy. Primordial follicles were characterized as an oocyte encircled by one layer of flattened cells. The buffalo primordial follicle has a mean diameter of $35 \mu \mathrm{m}$ and the oocyte diameter is $24.9 \mu \mathrm{m}$. The oocyte nucleus is relatively large and eccentric; and in the cytoplasm a large amount of mitochondria, vesicles and endoplasmic reticulum cistern, mainly of the smooth type is observed. The primordial follicles cells are rich in plasma membrane invaginations, which are observed within the cell and between the cell and the oocyte. The primary follicles (mean diameter of $41.8 \mu \mathrm{m}$ ) consist of an oocyte, with a medium diameter of $26.9 \mu \mathrm{m}$, surrounded by one layer of cubical granulosa cells. At this follicular stage, the beginning of zona pellucida deposition can also be seen in areas between the oocyte and follicular cells. The secondary follicles, which are surrounded by more than one layer of cubical cells, have a diameter of $53.3 \mu \mathrm{m}$, and the oocyte has a mean diameter of $29.4 \mu \mathrm{m}$. The ultrastructural analysis showed a large amount of coalescent vesicles, more evident in the oocyte periphery. The zona pellucida (ZP) is thicker at this stage and contains a large quantity of glycoproteins. In general, the ultrastructure of buffalo preantral follicles was similar to that of other mammalian species, but some differences were observed, which indicate species specific characteristics. The main differences observed were cytoplasmic vesicles quantity, mitochondria shape and inner content, ZP deposition and granulosa cell-oocyte junctions. In conclusion, the morphological differences described in this paper, could be responsible for some functional differences observed in Bubalus bubalis in vitro embryo production and follicular dynamics, when compared with Bos taurus or Bos indicus species.
\end{abstract}

Keywords: Buffalo; Transmission electron microscopy (TEM); Primordial follicle; Primary follicle; Secondary follicle

\section{Introduction}

The bubalines occupy specific market niches all over the world, producing milk, meat and work power. In the last 30 years, the bubaline world population $(172,263,305)$ has 
increased $34 \%$, while, in the same period, the cattle population has grown $12 \%$ (FAOSTAT, 2004). Since 1973, the world buffalo milk production increased 200\% (Rocha Loures, 2001).

In the growing world buffalo population, there are animals with greater genetic value to milk and meat production than other contemporaries. The genome of these animals must be multiplied by the use of reproductive technologies such as artificial insemination, embryo transfer, and in vitro embryo production (Baruselli and Carvalho, 2003).

The buffalo productivity is mainly impacted by the female reproductive efficiency. These animals, compared with cows, have a later puberty, are short day seasonal breeders (Baruselli et al., 1993) and a longer gestation period (Madan and Raina, 1984 and Madan, 1988). Other negative factors are the preantral follicles population in the buffalo female ovaries which is estimated to be 19,000 structures (Samad and Nasseri, 1979). This number is almost 10 times less than in cattle (Erickson, 1966), and it is probably the main cause of a lesser number of antral follicles in the female buffalo as compared with many other species (Manik et al., 2002).

To increase our knowledge of preantral follicle development in buffalo ovaries, the aim of the present study is to describe the morphological and ultrastructural aspects of ovarian follicular development during the preantral phases in the adult buffalo ovary. Oocyte and granulosa cells of primordial, primary and secondary follicles were studied using light and transmission electron microscopy.

\section{Materials and methods}

\subsection{Ovaries}

Approximately 20 ovaries were obtained from 10 slaughtered healthy postpubertal age buffalo females. The animal's age ranged from 7 to 10 years, and the animals were postpubertal with estrous cycles at typical intervals before slaughter. The structures were maintained, for no more than $2 \mathrm{~h}$, at $30{ }^{\circ} \mathrm{C}$ in $0.9 \%$ saline solution, enriched with $200 \mathrm{IU} / \mathrm{mL}$ of penicillin and $200 \mu \mathrm{g} / \mathrm{mL}$ of streptomycin. After washing in the same solution, the ovaries were transferred to a PBS (phosphate buffered saline) solution, containing 5\% FCS (fetal calf serum) and $200 \mathrm{IU} / \mathrm{mL}$ of penicillin and $200 \mu \mathrm{g} / \mathrm{mL}$ of streptomycin. Small portions of ovarian cortex were dissected under stereomicroscope. 


\subsection{Classical histology tissue preparation}

Ovarian portions were fixed in Bouin fixative for $24 \mathrm{~h}$, dehydrated in ethanol, clarified with xylene and embedded in paraffin. Sequential sections ( $5 \mu \mathrm{m}$ thick) were cut, stained with hematoxylin eosin, and covered with a cover slip.

\subsection{Transmission electron microscopy tissue preparation}

The ovarian cortex portions were fixed in Karnovsky solution ( $2 \%$ of glutaraldehyde, $2 \%$ of paraformaldehyde, $3 \%$ of sucrose, in a $0.1 \mathrm{M}$ sodium cacodylate buffer, $\mathrm{pH} 7.2$ ) at $4{ }^{\circ} \mathrm{C}$ for $24 \mathrm{~h}$. The post-fixation was performed with osmium tetroxide. The material was then contrasted in block with uranyl acetate $3 \%$ and the tissue was dehydrated with acetone. To utilize the semi-thin sections $(2 \mu \mathrm{m})$, the tissue blocks were included in Spurr. To classify the preantral follicles, the sections were dyed with toluidine blue and observed under light microscopy. The ultrathin sections $(90 \mathrm{~nm})$ were made from follicles with intact nucleus and were contrasted with uranyl acetate and lead citrate to be observed with transmission electron microscopy (Jeol 1011) operated at $80 \mathrm{Kva}$.

\subsection{Follicular analysis}

For histological description, preantral follicles were classified as primordial, primary or secondary according to the shape and number of layers of granulosa cells. The histological sections used in the present study were taken from fragments of 10 ovaries, collected from 10 different buffalo females. Each fragment was obtained by a transversal cut in the central region of the ovary and only one histological section per ovary was used for the results. Follicular and oocyte diameters were measured using an ocular micrometer at the oocyte equatorial region, with the presence of oocyte nucleus. To determine the number of granulosa cells surrounding the follicle, the nuclei were counted in the follicle equatorial region. Follicles that contained pyknotic bodies in granulosa cells, condensed oocyte nucleus, shrunken oocyte or low cellular density were considered naturally degenerated (atretic follicles) and, therefore, were not used for the morphometric characterization.

For description by transmission electron microscopy, the characteristics of oocyte and granulosa cell nuclei, cytoplasm, organelles, basal membrane and zona pellucida (ZP) were 
observed. Only those follicles with normal morphology on semi-thin sections were ultrastructurally evaluated.

\subsection{Statistical analysis}

Data were treated by analysis of variance, using follicle type as a fixed effect and follicle and oocyte diameters as dependent variables. The means were compared using the Tukey test. The regression analysis was performed considering the follicle diameter in relation to oocyte diameter. All statistical analyses were conducted using SAS System for Windows, SAS Institute Inc., Cary, NC, USA. Values were considered statistically significant when $\mathrm{P}<0.05$.

\section{Results}

\subsection{Morphometry and light microscopy}

Primordial follicles consisted of an oocyte surrounded by one layer of flattened or flattened-cuboidal granulosa cells (Fig. 1A). In primary follicles, the oocyte was surrounded by one layer of cuboidal granulosa cells (Fig. 1B). Initial secondary follicles are characterized by the beginning of granulosa cell bilayer formation, and it was noted that layer duplication is very irregular (Fig. 1C). Secondary follicles consisted of an oocyte surrounded by two or more layers of cuboidal granulosa cells. The morphometric data for primordial, primary and secondary follicles are presented in Table 1. The number of each class of follicles presented in Table 1 is the total number used for measurement. The number of primordial and secondary follicles in the ovary is less than the number of primary follicles (Table 1). There was a highly significant linear regression, considering the follicle as dependent variable (Fig. 2). The equations for primordial, primary and secondary follicles were, respectively, $y=0.6013 x+$ $20.075 ; y=0.8245 x+19.617$ and $y=1.8142 x+0.0525$ 

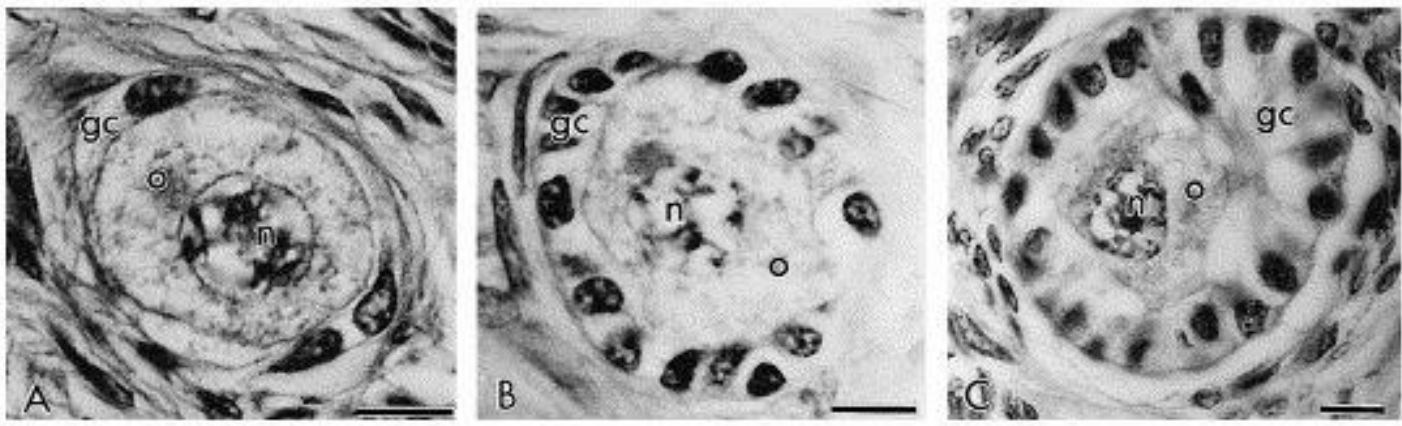

Fig. 1. Light micrographs showing (A) primordial, (B) primary, and (C) secondary buffalo follicles. $O$, oocyte; $\mathrm{n}$, oocyte nucleus; gc, granulosa cell. Bar $=10 \mu \mathrm{m}$.

Table 1

Follicle and oocyte diameter of primordial, primary, and secondary buffalo follicles (mean \pm S.D.)

\begin{tabular}{llll}
\hline Follicular classes & $N$ & Follicle diameter $(\mu \mathrm{m})(\mathrm{range})$ & Oocyte diameter $(\mu \mathrm{m})(\mathrm{range})$ \\
\hline Primordial & 17 & $35.0 \pm 3.11 \mathrm{a}(29-39)$ & $24.9 \pm 3.69 \mathrm{a}(19-26)$ \\
Primary & 57 & $41.8 \pm 4.83 \mathrm{~b}(38-55)$ & $26.9 \pm 3.84 \mathrm{a}, \mathrm{b}(17-31)$ \\
Secondary & 23 & $53.3 \pm 12.04 \mathrm{c}(38-75)$ & $29.4 \pm 5.39 \mathrm{~b}(21-36)$ \\
\hline
\end{tabular}

Values with different letters $(a-c)$ differ within column $(P<0.05)$.

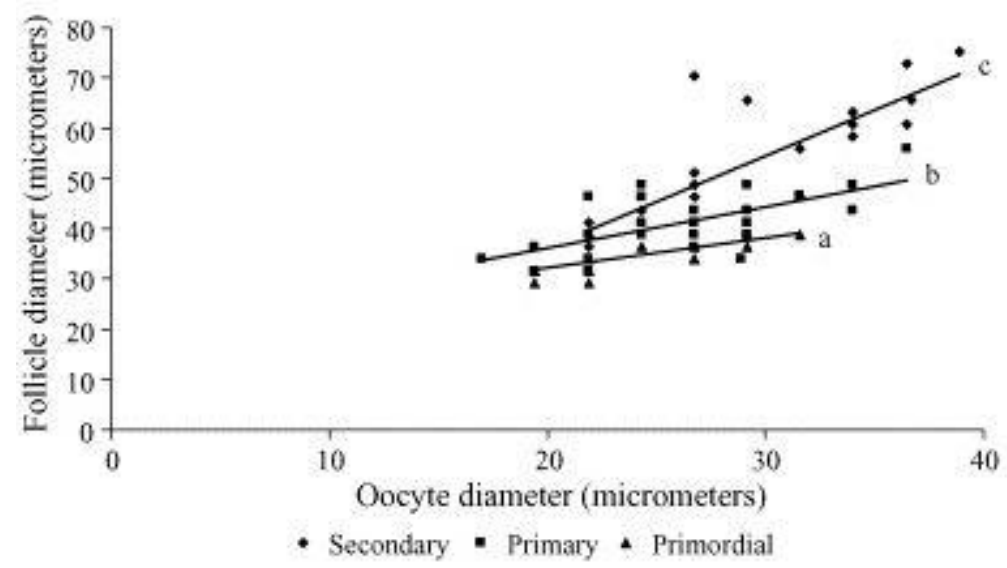

Fig. 2. Scatter chart showing the relation between oocyte and follicle diameter. The tendency lines for primordial (a), primary (b) and secondary (c) follicles are also represented.

\subsection{Primordial follicle ultrastructure}

The ovoid to spherical oocyte of the primordial follicles was surrounded by 4-8 flattened granulosa cells at the equatorial section (Fig. 1A). In general, a large number of vesicles with different diameters and containing undefined material were observed in the ooplasm. The oocyte nucleus occupied a central or eccentric position and the cytoplasmic organelles were concentrated between the vesicles and scarce myelin figures. These figures were observed in granulosa cell cytoplasm (Fig. 3A). The mitochondria were predominantly round with transversal cristae, and in some cases mitochondria that appears to be dividing in 
two or three were observed. Rough endoplasm reticulum cisternae were observed in most cases in association with oocyte mitochondria, but were also seen isolated within the ooplasm and in the cytoplasm of granulosa cells this organelle was very well developed. In the ooplasm, a delimited region with a well developed smooth endoplasmic reticulum could be observed (Fig. 3B). This characteristic could be seen in all of the oocytes which appeared with a nucleolus, indicating that this feature occurred at the exact equatorial region, i.e. center of the oocyte. The ZP could not be seen at this stage, and the oocyte and granulosa cells appeared only juxtaposed, without any specific junctions. In some regions, between granulosa cells and oocyte there were apparent empty spaces (Fig. 3B).
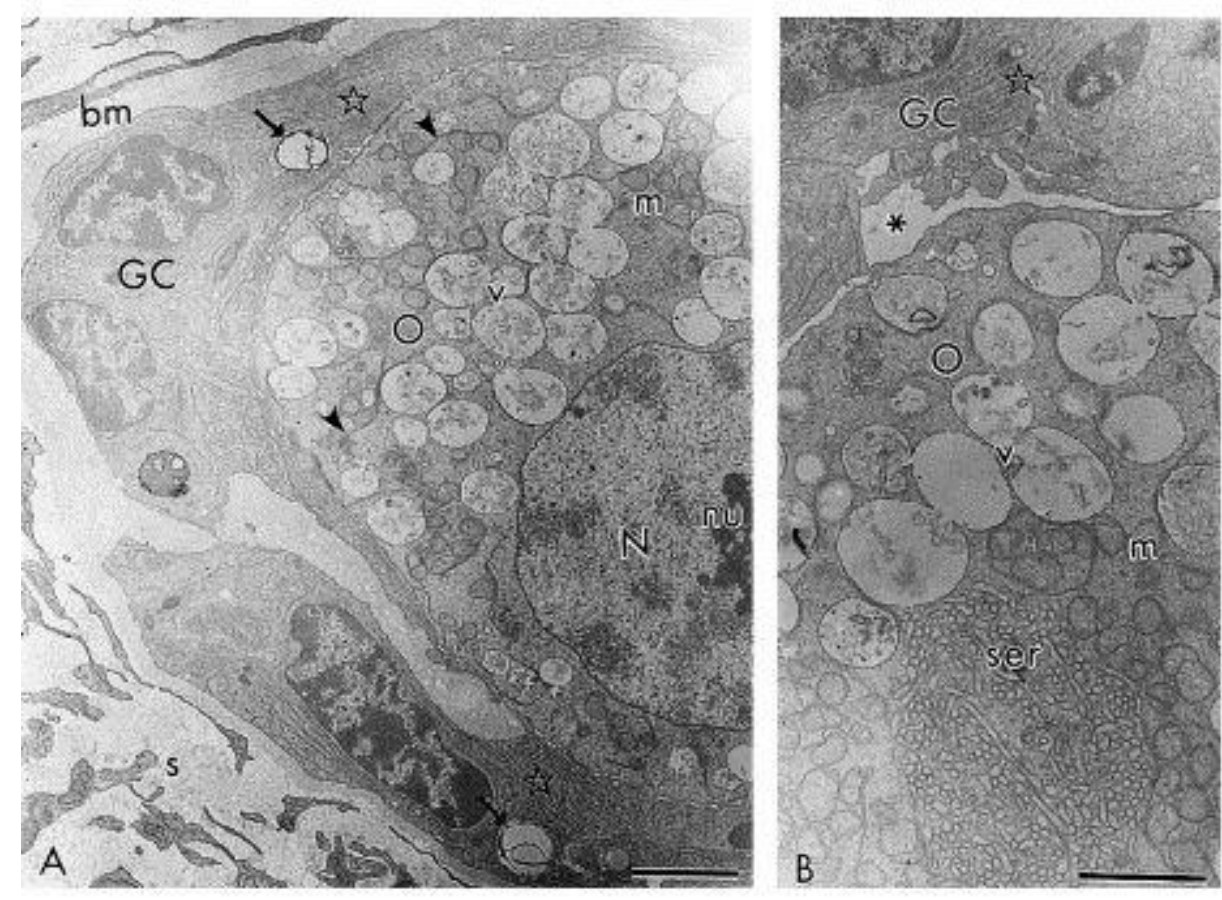

Fig. 3. Primordial follicle (TEM). Note the abundance of vesicles (v), the well developed smooth endoplasmic reticulum (ser), the myelin figures (arrows) and granulosa cell rough endoplasmic reticulum (open star). s, stroma; bm, basal membrane; GC, granulosa cell; O, oocyte; N, nucleus; nu, nucleolus; m, round shaped mitochondria; oocyte endoplasma reticulum (arrowhead); *: zona pellucida space. Bar = $0.4 \mu \mathrm{m}$ (A); $0.2 \mu \mathrm{m}$ (B).

\subsection{Primary follicle ultrastructure}

The predominantly spherical oocyte was surrounded by a single layer of $8-20$ granulosa cells at the equatorial section (Fig. 1B). Some patches of ZP appeared to be present in a few follicles between the oocyte and the surrounding granulosa cells (Fig. 4A). Embedded in ZP patches, the oolemma contained projections that penetrated in between adjacent 
granulosa cells. The ooplasma remained full of vesicles and apparently these structures have a greater coalescence rate when compared with primordial follicles (Fig. 4B).
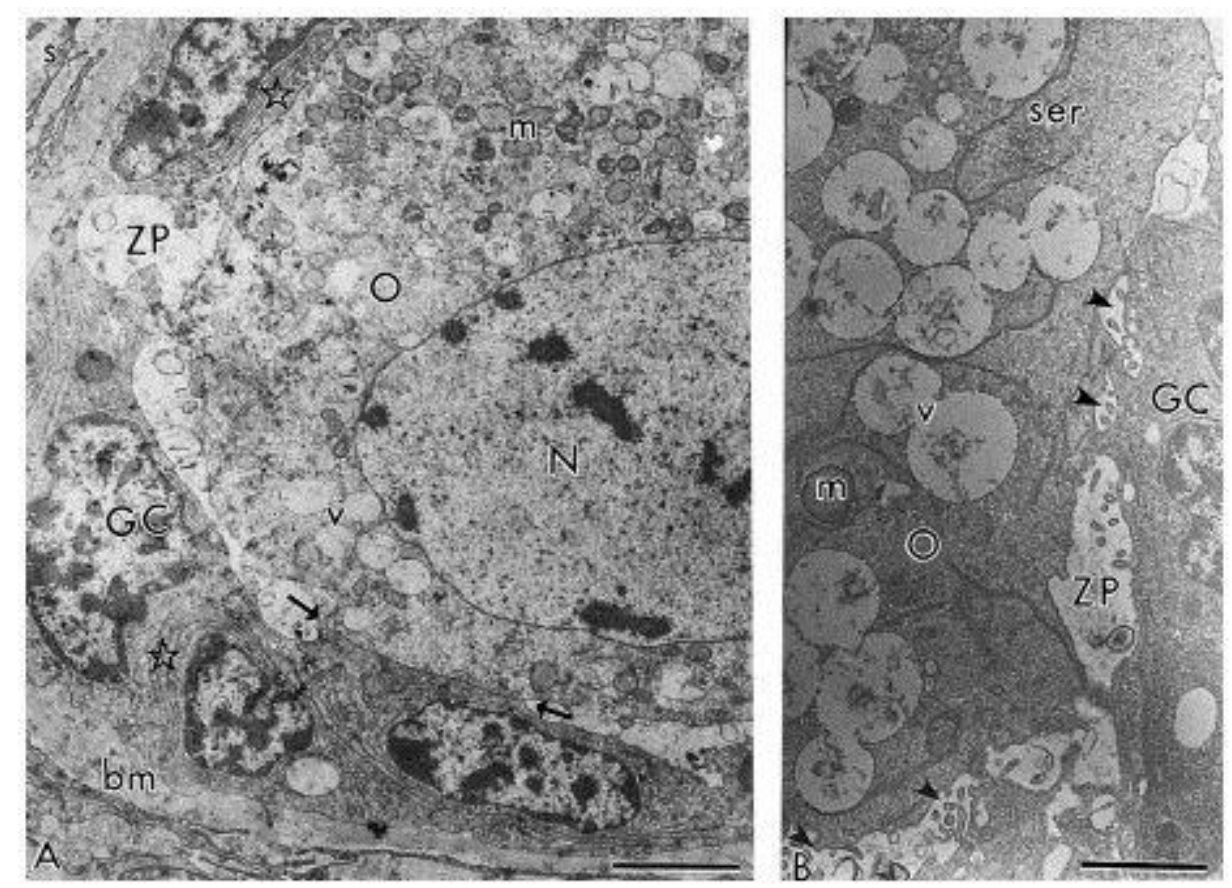

Fig. 4. Primary follicle (TEM). Note the beginning of zona pellucida deposition (ZP), the microvilli embedded (arrowhead) and granulosa cell rough endoplasmic reticulum (open star). Arrows delimit oocyte-granulosa cell membrane juxtaposition. s, stroma; bm, basal membrane; $G C$, granulosa cell; $O$, oocyte; $N$, nucleus; $m$, round shaped mitochondria; ser, smooth endoplasmic reticulum; $v$, coalescent vesicles. $B a r=0.4 \mu \mathrm{m}(\mathrm{A}) ; 0.2 \mu \mathrm{m}$ (B).

\subsection{Secondary follicles}

Round mitochondria were still more abundant, and elongated mitochondria were rarely observed. Lipid droplets were observed in the deep cortical region of some oocytes, and dark granules could be seen within some vesicles (Fig. 5A). Interestingly, in this category, some granulosa cells developed a columnar shape, instead of regular cubical form (Fig. 5B). Patches of ZP material were observed in all structures and were usually associated with erect microvilli. A large amount of coalescent vesicles was observed, sometimes complicating the organelles visualization. Some vesicles appeared to migrate to the oolemma for exocytosis. The myelin figures were more abundant in secondary follicles, oocytes, and granulosa cells (Fig. 6) than in the other developmental stages. 

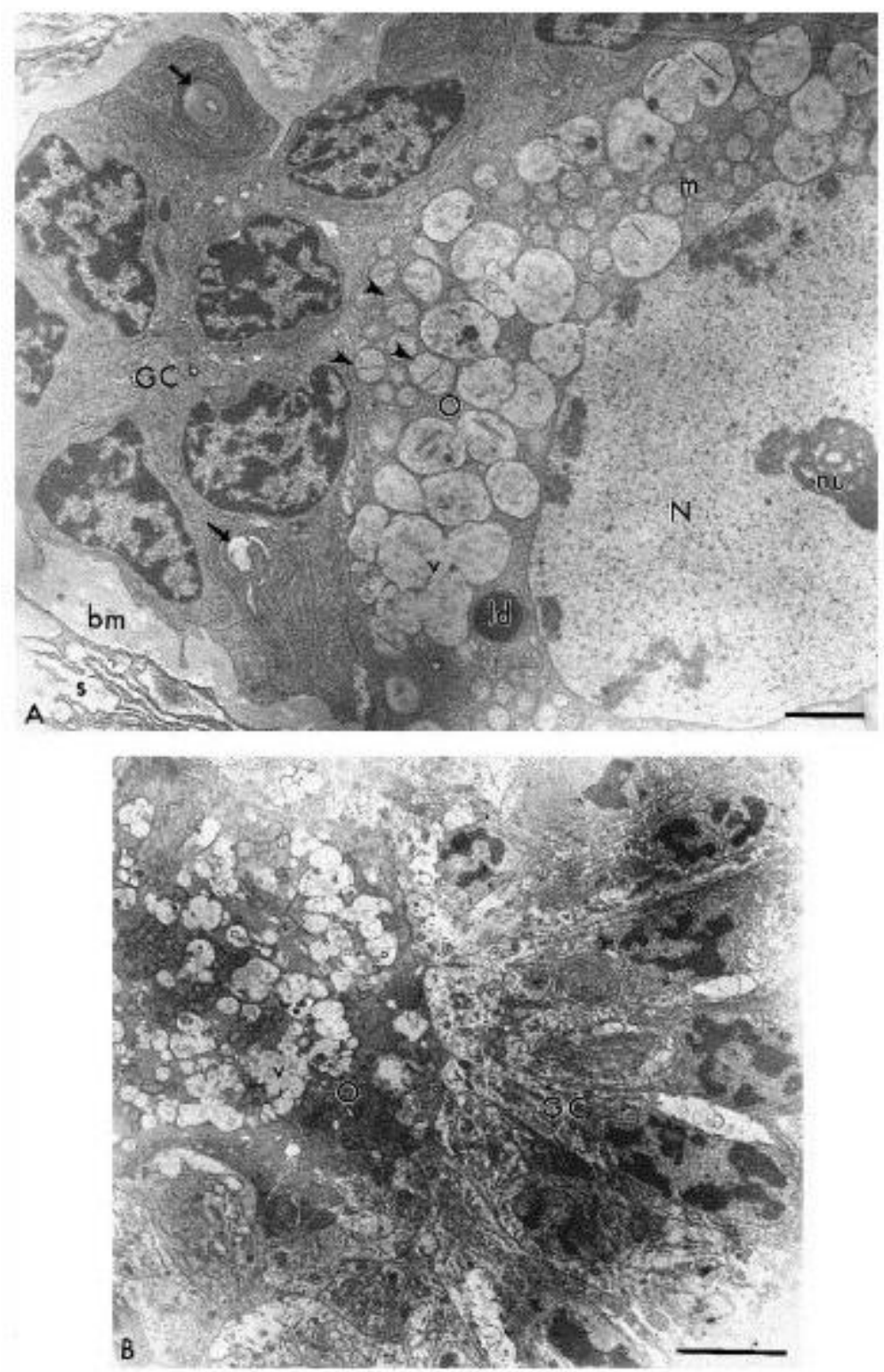

Fig. 5. Secondary follicle (TEM). Note the dividing mitochondria (arrowhead), the columnar granulosa cells in (b) and the myelin figures (arrows). s, stroma; bm, basal membrane; GC, granulosa cell; $\mathrm{O}$, oocyte; N, nucleus; nu, nucleolus; $m$, round shaped mitochondria; $v$, coalescent vesicles; Id, lipid droplet. $\operatorname{Bar}=0.2 \mu \mathrm{m}(\mathrm{A}) ; 0.4 \mu \mathrm{m}(\mathrm{B})$. 


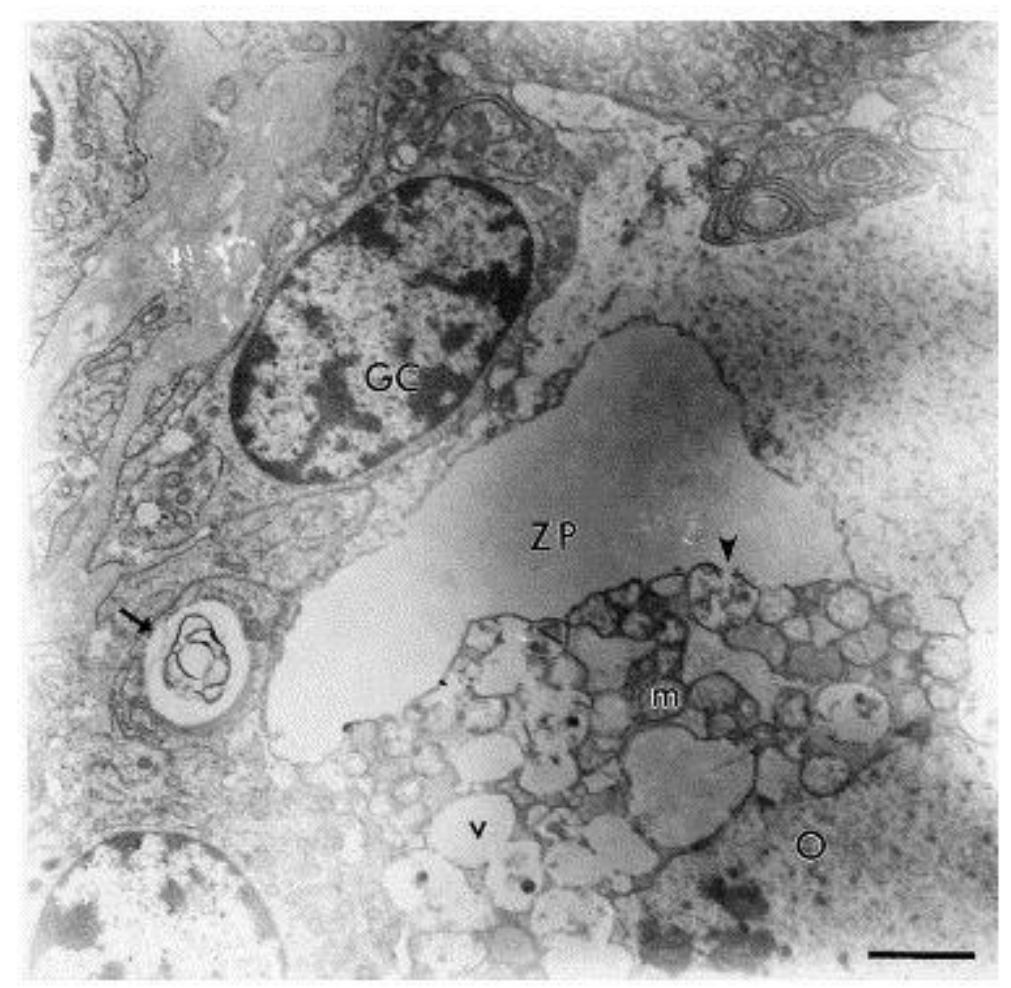

Fig. 6. Detail of secondary follicle (TEM). Note the vesicle exocytosis (arrowhead) and the myelin figures (arrows). GC, granulosa cell; O, oocyte; $\mathrm{m}$, round shaped mitochondria; $v$, coalescent vesicles; ZP, zona pellucida. Bar $=0.2 \mu \mathrm{m}$.

\section{Discussion}

The growth of the buffalo primordial follicle to the secondary stage is manifested by the proliferation and differentiation of the granulosa cells and an increase in oocyte diameter from approximately 25 to $29 \mu \mathrm{m}$. As already described for cattle (Fair et al., 1997), the granulosa proliferation and restructuring are the first morphological features to be noted at primordial follicle activation in buffalo.

The results showed that the mean diameter of buffallo oocytes and follicles, and the mean number of granulosa cells at the equatorial section were less than those observed for European (Hyttel et al., 1997), and Zebu (Kacinskis et al., 2005) cattle in all three developmental stages (i.e., primordial, primary and secondary follicles). In addition, the buffalo follicles and oocyte diameters, in each category, are similar as those described for mice (Bayrak and Oktay, 2003), and greater than that of sheep (Lundy et al., 1999 and van den Hurk and Zhao, 2005) and goats (Lucci et al., 2001). As described by van Wezel and Rodgers (1996) for European cattle, the granulosa cells of buffalo follicles are clustered at two opposite poles on the long axis of each structure, giving a prolate shape to the follicle. Besides the follicular renewal described in postnatal mouse ovary (Johnson et al., 2004), the lesser overall number 
of primordial follicles (Table 1) observed in the present study could be explained by buffalo having a longer reproductive life than cows, ewes and goats, and the pool of primordial follicles could be almost exhausted because the slaughtered animals had an advanced age. Moreover, the greater number of primary follicles, compared with primordial and secondary, could be caused by the time required for follicular development from primordial to primary and primary to secondary stages.

In general, the ultrastructure of buffalo preantral follicles was similar to that of other mammalian species (cattle: van Wezel and Rodgers, 1996, Hyttel et al., 1997 and Kacinskis et al., 2005; pig: Greenwald and Moor, 1989; feline: Jewgenow and Stolte, 1996; human: Oktay et al., 1997; and goat: Lucci et al., 2001), but some differences were observed, which indicate species specific characteristics. The main differences observed were cytoplasmic vesicles quantity, mitochondria shape and inner content, ZP deposition and granulosa cells-oocyte junctions. The morphological differences described in this paper could be responsible for some functional differences observed in Bubalus bubalis in vitro embryo production ( Neglia et al., 2003) and follicular dynamics (Manik et al., 2002), when compared with Bos taurus or Bos indicus species.

A greater amount of cytoplasmic vesicles was also observed by Boni et al. (1992) in fully developed buffalo oocytes. In the present assessment, these structures were present in the oocytes from the beginning of follicle development which was completely different from that observed in cattle (Fair et al., 1997) and other species. It was also noted that during preantral follicle development, these vesicles tend to coalesce. The large number of these structures, occupying a vast volume of the ooplasm and their greater number when compared with any known functional organelles, may cause the apparently lesser capacity of buffalo oocytes to develop into embryos in in vitro systems. Concerning vesicle exocytosis, it could be inferred that these structures contain ZP material or some oocyte-granulosa cell communication molecules.

In the present study, the mitochondria of the quiescent oocyte were predominantly round with transversal cristae, and different from cattle (Fair et al., 1997) as these maintain this shape until secondary follicle development. Furthermore, the mitochondrial granules observed in other species are not present in buffalo.

Considering the junctions between oocyte and granulosa cells in the present study, no type of specific junction was observed, although, in cattle, adherens junctions were detected between granulosa cells and oocyte because primordial follicles, and gap and zonula adherenslike junctions were also observed between adjacent granulosa cells (Fair and Hyttel, 1997 and Kacinskis et al., 2005). Desmosomes were observed joining follicular cells to each other and/or 
to the oocyte in cats (Jewgenow and Stolte, 1996), monkeys (Zamboni, 1974) and rabbits (Nicosia et al., 1975). However, in buffalo, as observed in goats (Lucci et al., 2001), special types of junctions (i.e. desmosomes, adherens or tight junctions) were not observed among granulosa cells or between granulosa cells and oocytes. In this latter situation, only the endocytotic contact was clearly visible. Specifically, regarding gap junctions, the reason why they were not observed in the present study may be that none of the follicles evaluated by transmission electron microscopy had the oocyte completely surrounded by ZP. Thus, it can be inferred that while the ZP is not fully developed around the whole oocyte, gap junctions are not necessary to maintain viability, and, therefore, not present at this stage of development. At this stage, substances required for the oocyte metabolic needs could gain access to its cytoplasm by diffusion through the closely opposed membranes of oocyte and granulosa cells in the areas of intercellular contact, or these materials could be incorporated by endocytosis. Whatever the way of contact between oocyte and granulosa cells, this association is extremely important for oocyte growth. The granulosa cells cooperate in oocyte metabolic processes and this cooperation is probably essential for normal oocyte development. Isolated oocytes normally grow in vitro only when association with the companion granulosa cells is maintained and the rate of oocyte growth in vitro is directly correlated with the number of granulosa cells coupled to the oocyte (McNatty et al., 1999).

When the primary follicle is established the first traces of ZP material were observed in the present study. This result is different from the findings of Rüsse (1983) and Fair et al. (1997) for cattle where the ZP deposition is established only at the secondary stage of development. The initial appearance of the ZP coincides with the appearance of an increased number of microvilli on the oocyte surface and with the formation of granulosa cell process endings in the present study. The ZP was formed in patches over the oocyte perimeter and between granulosa cells. The ZP glycoproteins are synthesized in the rough endoplasmic reticulum (RER) and modified in the Golgi complex, where these are packed into vesicles that migrate to the oolemma for exocytosis (for review, Dunbar et al., 1994). The presence of extensive tubules of RER in the granulosa cells as noted in the present study would appear to create the cellular structures for the production of ZP material in these cells, as previously described in dog ovaries (Blackmore et al., 2004). However, actual exocytosis of ZP material from the oocyte or granulosa cells was not observed.

The well developed smooth endoplasmic reticulum, present mainly in primordial follicles, seems to be responsible for lipid biosynthesis and consequent lipid droplets formation in later oocyte developmental stages. Myelin figures, as described in other species (Miranda et al., 1999 and Kacinskis et al., 2005), observed in follicles and granulosa cells are thought to 
represent digestive vesicles responsible for degradation of aged and non-functional cellular structures (Fawcett, 1966). Oocytes are cells with a very long developmental stage, taking years to leave the quiescent stage and then months to get fully developed. The renewal of organelles, principally in secondary follicles, may be necessary, and the myelin figures observed in the present study might possibly represent digestive vesicles of aged oocyte organelles.

In conclusion, the present study demonstrates, for the first time an ultrastructural description of buffalo preantral follicles. In general, the results indicate that the morphology and the ultrastructure of buffalo preantral follicles resemble that of other mammals. However, some differences were observed, and may indicate species specific differences. An insight into the fine structural organization of buffalo follicles would be of benefit in explaining cellular and molecular aspects of follicle growth and atresia in this species. Moreover, basic knowledge on the ultrastructure of preantral follicles may facilitate the understanding of their in vitro development.

Acknowledgement

This research was supported by CNPq, CAPES, FINEP and FINATEC.

\section{References}

Baruselli, P.S., Carvalho, N.A.T., 2003. Controle do desenvolvimento folicular para o emprego de biotecnologias da reproduc, ao em bubalinos ( Bubalus bubalis). Rev. Bras. Reprod. An. 27, 94-102.

Baruselli, P.S., Oliveira, J.F.S., Mendes, M.L.M., Jorge, A.M., Fujii, T., Palazzo, J.P.C., 1993. Diagnostico da bubalinocultura do Vale do Ribeira. Documento Tecnico CATI 94, 16.

Bayrak, A., Oktay, K., 2003. The expression of cyclin-dependent kinase inhibitors p15, p16, p21, and p27 during ovarianfollicle growth initiation in the mouse. Reprod. Biol. Endocr. 41, http://www.rbej.com/content/1/1/41.

Blackmore, D.G., Baillie, L.R., Holt, J.E., Dierkx, L., Aitken, R.J., McLaughlin, E.A., 2004. Biosynthesis of the canine zona pellucida requires the integrated participation of both oocytes and granulosa cells. Biol. Reprod. 71, 661-668.

Boni, R., Santella, L., Dale, B., Roviello, S., Di Palo, R., Barbieri, V., 1992. Maturazione in vitro di oociti buffalini: indagine ultrastrutturale. Acta Med. Vet. 38, 153-161.

Dunbar, B.S., Avery, S., Lee, V., Prasad, S., Schwahn, D., Schwoebel, E., Skinner, S., Wilkins, B., 1994. The mammalian zona pellucida: its biochemistry, immunochemistry, molecular biology, and developmental expression. Reprod. Fertil. Dev. 6, 331-347. 
Erickson, B.H., 1966. Development and senescence of the postnatal bovine ovary. J. Anim. Sci. $25,800-805$.

Fair, T., Hyttel, P., 1997. Oocyte growth in cattle-ultrastructure, transcription and developmental competence. Microsc. Reprod. Dev.: A Dyn. Approach, 109-118.

Fair, T., Hulshof, S.C.J., Hyttel, P., Greve, T., Boland, M., 1997. Oocyte ultrastructure in bovine primordial to early tertiary follicles. Anat. Embryol. 195, 327-336.

FAOSTAT, 2004. Statistical data from Food and Agriculture Organization of the United Nations, http://faostat.fao.org/.

Fawcett, D.W., 1966. An Atlas of Fine Structure-The Cell: Its Organelles and Inclusions, 1st ed. W.B. Saunders Company, Philadelphia and London.

Greenwald, G.S., Moor, R.M., 1989. Isolation and preliminary characterization of pig primordial follicles. J. Reprod. Fertil. 87, 561-571.

Hyttel, P., Fair, T., Callesen, H., Greve, T., 1997. Oocyte growth, capacitation and final maturation in cattle. Theriogenology 47, 23-32.

Jewgenow, K., Stolte, M., 1996. Isolation of preantral follicles from nondomestics catsviability and ultrastructural investigations. Anim. Reprod. Sci. 44, 183-193.

Johnson, J., Canning, J., Kaneko, T., Pru, J.K., Tilly, J.L., 2004. Germline stem cells and follicular renewal in the postnatal mammalian ovary. Nature 428, 145-150.

Kacinskis, M.A., Lucci, C.M., Luque, M.C.A., Bao, S.N., 2005. Morphometric and ultrastructural characterization of 'Bosindicus preantral follicles. Anim. Reprod. Sci. 47, 45-57.

Lucci, C.M., Silva, R.V., Carvalho, C.A., Figueiredo, J.R., Bao, S.N., 2001. Light microscopical and ultrastructural 'characterization of preantral follicles. Small Rumin. Res. 41, 61-69.

Lundy, T., Smith, P., O'connell, A., Hudson, N.L., Mcnatty, K.P., 1999. Population of granulosa cells in small follicles of the sheep ovary. J. Reprod. Fertil. 115, 251-262.

Madan, M.L., 1988. Status of reproduction in female buffalo. In: Buffalo Production and Health: A Compendium of Latest Research Information Based on Indian Studies. ICAR publications, New Delhi, India.

Madan, M.L., Raina, V.S., 1984. Fertility and performance of buffaloes under tropical conditions. In: Proceedings of the 10th International Congress on Animal Reproduction and Artificial Insemination, vol. 2, Illinois, pp. 142.1-142.4.

Manik, R.S., Palta, P., Singla, S.K., Sharma, V., 2002. Folliculogenis in buffalo (Bubalus bubalis): a review. Reprod. Fertil. Dev. 14, 315-325.

McNatty, K.P., Heath, D.A., Lundy, T., Fidler, A.E., Quirke, L., O'Connell, A., Smith, P., Groome, N., Tisdall, D.J., 1999. Control of early ovarian follicular development. J. Reprod. Fertil. Suppl. $54,3-16$. 
Miranda, A.C.L., Bazzoli, N., Rizzo, E., Sato, Y., 1999. Ovarian follicular atresia in two teleost species: a histological and ultrastructural study. Tissue Cell 31, 480-488.

Neglia, G., Gasparrini, B., di Brienza, V.C., Di Palo, R., Campanile, G., Presicce, G.A., Zicarelli, L., 2003. Bovine and buffalo in vitro embryo production using oocytes derived from abattoir ovaries or collected by transvaginal follicle aspiration. Theriogenology 59, 1123-1130.

Nicosia, S.V., Evangelista, I., Batta, S.K., 1975. Rabbit ovarian follicles. I. Isolation technique and characterization at different stages of development. Biol. Reprod. 13, 423-447.

Oktay, K., Nugent, D., Newton, H., Salha, O., Chatterjee, P., Gosden, R.G., 1997. Isolation and characterization of primordial follicles from fresh and cryopreserved human ovarian tissue. Fertil. Steril. 67, 481-486.

Rocha Loures, R., 2001. Buffalo production system in Americas. In: Proceedings of the Sixth World Buffalo Congress, Maracaibo, Venezuela, pp. 74-86.

Russe, I., 1983. Oogenesis in cattle and sheep. Bibl. Anat. 24, 77-92.

Samad, H.A., Nasseri, A.A., 1979. A quantitative study of primordial follicles in buffalo heifer ovaries. In: Compendium, 13th FAOrSIDA International Course on Animal Reproduction, Uppsala, Sweden. van den Hurk, R., Zhao, J., 2005. Formation of mammalian oocytes and their growth, differentiation and maturation within ovarian follicles. Theriogenology 63, 1717-1751.

van Wezel, I.L., Rodgers, R.J., 1996. Morphological characterization of bovine primordial follicles and their environment in vivo. Biol. Reprod. 55, 1003-1011.

Zamboni, L., 1974. Fine morphology of the follicle wall and follicle cell-oocyte association. Biol. Reprod. 10, 125-149. 